\title{
A heterogeneidade discursiva no discurso de Dilma Rousseff: uma análise do discurso relatado na sua carta de defesa e no seu último pronunciamento como presidenta
}

\author{
La heterogeneidad discursiva en el \\ discurso de Dilma Rousseff: un análisis \\ del discurso relatado en su carta de \\ defensa e en su último \\ pronunciamiento como presidenta
}

Andrêssa dos Santos Galvão ${ }^{1}$

Resumo: No presente artigo analisamos, no âmbito da Análise de Discurso de filiação pecheuxtiana, o discurso da expresidenta Dilma Vana Rousseff. Tomamos como corpus empírico a carta de defesa enviada, pela então presidenta, ao Senado Federal, em 16 de agosto de 2016; e seu último pronunciamento, como presidenta, antes de sua defesa final, em 29 de agosto do referido ano, com o objetivo central de analisar a heterogeneidade discursiva presente nos documentos citados. Para tanto, centramos a análise na heterogeneidade mostrada (marcada ou não), através do discurso relatado, atentando para: i. o discurso relatado marcado; ii. o discurso relatado indireto formal; iii. o discurso relatado indireto informal; iv. Os efeitos de sentido decorrentes da heterogeneidade discursiva.

Palavras-chave: Heterogeneidade discursiva; Discurso relatado; Discurso-outro, Discurso de Dilma; Formação discursiva. 
Resumen: En el presente artículo analizamos, en el ámbito del Análisis de Discurso de filiación pecheuxtiana, el discurso de la ex presidente Dilma Vana Rousseff. Tomamos como corpus empírico la carta de defensa enviada, por la entonces presidenta, al Senado Federal, el 16 de agosto de 2016; y su último pronunciamiento, como presidenta, antes de su defensa final, el 29 de agosto del referido año, con el objetivo central de analizar la heterogeneidad discursiva presente en dichos documentos. Para eso, centramos el análisis en la heterogeneidad mostrada (marcada o no), a través del discurso relatado, atentando para: i. el discurso relatado marcado; ii. el discurso relatado indirecto formal; iii. el discurso relatado indirecto informal; iv. los efectos de sentido decurrentes de la heterogeneidad discursiva.

Palabras-clave: Heterogeneidad discursiva; Discurso relatado; Discurso-otro; Discurso de Dilma; Formación discursiva.

\section{Considerações iniciais}

Neste artigo, analisamos o discurso de autodefesa ${ }^{2}$ de Dilma Vana Rousseff ${ }^{3}$, focando na carta, enviada pela então presidenta ao Senado Federal, e seu pronunciamento final, enquanto presidenta, em 16 e 29 de agosto de 2016, respectivamente, e tendo como pano de fundo o processo de impeachment, que gerou uma comoção nacional e internacional, visto que, de um lado, defendia-se que a presidenta havia cometido crimes que legitimavam seu afastamento, e de outro, sustentava-se que ela estava sendo vítima de um "golpe" e que o processo era uma via de acesso para um governo ilegítimo.

Durante o processo, uma crise política e econômica se abateu sobre o país e foram deflagradas inúmeras prisões de políticos e empresários envolvidos em escândalos de corrupção. Diante desse cenário, consideramos importante refletir sobre os efeitos de sentido produzidos pelo discurso da presidenta. Nessa perspectiva, entendemos importante compreender de que modo o discurso de Dilma é atravessado por outros discursos que marcam as diferentes posições-sujeito que, por sua vez, se inscrevem em diferentes formações discursivas. Além disso, o embate de forças, travado durante o processo de impeachment, fez vir à tona uma discursividade fortemente marcada pelo político, aqui entendido como relações de força que se trava na sociedade (presentes na sociedade) que no nosso entender merece um estudo.

Entendemos que o impeachment de Dilma foi um acontecimento histórico que deu início a uma série de eventos que mudou o cenário sócio-político do Brasil, daí a importância de partirmos da carta e do pronunciamento da presidenta, atentando para a heterogeneidade discursiva mostrada (marcada ou não) presente nos referidos documentos.

Authier-Revuz (2004, p. 12) defende que é no fio do discurso que, real e materialmente, um locutor único produz um certo número de formas, as quais são linguisticamente detectáveis no nível da frase ou do discurso. Essas formas, por sua vez, inscrevem em sua linearidade, o outro ${ }^{4}$. Assim, entendemos que nossa reflexão é significativa, dado que fortalece a concepção de que o discurso de um sujeito não tem origem nele, mas deriva sentidos da memória discursiva. Desta forma, partimos de

\footnotetext{
2 Nosso corpus empírico reúne duas peças: a carta (escrita) de Dilma, enviada ao Senado, e seu último pronunciamento (escrito), antes de sua defesa final. Portanto, quando falamos em discurso de autodefesa, nos referimos a essas duas peças, especificamente.

3 Optamos, neste trabalho, utilizar as formas "presidenta", "presidenta Dilma" e "Dilma" ao nos referirmos à presidenta Dilma Vana Rousseff.

4 Compreendemos que o "outro", para a AD, corresponde ao discurso-outro, que é da ordem do complexo das formações discursivas, ou seja, do interdiscurso, uma vez que o mesmo corresponde ao "isso fala", o "sentido já-lá" (Orlandi, 1990, p. 39) - é a partir da relação entre o intradiscurso com o interdiscurso, que o dizer do sujeito é remetido ao Outro constitutivo (interdiscurso), haja vista que todos os dizeres aí estão.
} 
Authier-Revuz, pois foi ela que cunhou a noção de heterogeneidade. Porém, utilizamos, também, os trabalhos desenvolvidos no âmbito da Análise de discurso de filiação pecheuxtiana (AD), como base para a reflexão que será desenvolvida.

\section{A heterogeneidade discursiva através do discurso relatado}

Empreendemos, aqui, uma discussão acerca da heterogeneidade discursiva que irrompe no discurso que analisamos, através do discurso relatado. Indursky (2013, p. 241) entende que "o discurso relatado é apenas o sintoma da natureza essencialmente heterogênea de qualquer discurso", ou seja, é uma forma de apreensão da fala do outro; sendo possível, através dele examinar a heterogeneidade do discurso.

Neste ínterim, nos apoiamos, metodologicamente, na classificação proposta por Indursky (2013, p. 243), acerca das formas do discurso relatado. A autora salienta, contudo, que não se trata de uma nova nomenclatura.

Indursky (2013, p. 243) elenca três modalidades do discurso relatado: i. Discurso relatado marcado (DRM); ii. Discurso relatado indireto formal (DRIF); e iii. Discurso relatado indireto informal (DRII). A primeira modalidade caracteriza-se por citar palavras, expressões, enunciados entre aspas; a segunda corresponde, com exatidão, ao discurso indireto; e a terceira modalidade é uma variante da segunda, porém, não possui uma sintaxe passível de formalização, isto é, não apresenta identidade com a sintaxe que caracteriza o discurso indireto.

Note-se que o DRM e o DRIF podem ser apreendidos a partir de marcas no texto, ou seja, estamos diante de formas da heterogeneidade mostrada marcada, ou, como compreende Authier-Revuz (2004, p. 12), são modalidades em que o locutor "dá lugar explicitamente ao discurso de um outro em seu próprio discurso". Já no caso do DRII, temos uma forma mostrada não marcada, haja vista que não há separação entre o que diz o sujeito de $\mathrm{D} 1^{5}$ e o que diz o sujeito de $\mathrm{D} 2^{6}$, sendo necessário recorrer à categoria da memória discursiva para compreender como se dá a inserção do discurso-outro no discurso em pauta.

Nas análises que se seguem, é possível compreender como tais funcionamentos marcam um confronto entre FDs, dado que a partir de tais modalidades do discurso relatado é possível apreender o discurso-outro que é rejeitado pelo sujeito de D1 na busca de sua desqualificação. Buscamos também compreender os efeitos de sentido produzidos no processo de inserção do discurso-outro. De tal modo, na análise, que está dividida em sub-recortes ${ }^{7}$, apresentamos as sequências discursivas representativas de diferentes maneiras de inserção do discurso-outro no discurso em pauta.

5 D1: Discurso representativo da posição-sujeito que que se inscreve na Formação Discursiva Interna.

6 D2: Discurso representativo da posição-sujeito que se inscreve na Formação Discursiva Externa.

7 Compreendemos que o sub-recorte diz respeito a distintos funcionamentos linguísticos que mostram o mesmo funcionamento discursivo, isto é, no caso de haver mais de uma forma de funcionamento do discurso-outro, este será compreendido como sub-recorte. 


\title{
A heterogeneidade da formação discursiva
}

Para compreender a heterogeneidade discursiva no seio da $A D$, precisamos apreender a concepção de formação discursiva (FD), visto que a própria FD é considerada como heterogênea em relação a si mesma, ou seja, o seu fechamento é instável, não havendo um limite que separe o seu interior e seu exterior (COURTINE \& MARANDIN, 2016, p. 39).

Pêcheux traz de Foucault a noção de formação discursiva. Para Foucault (2008, p. 43), na possibilidade de se descrever, entre um certo número de enunciados, um sistema semelhante de dispersão, e no caso em que entre os objetos, os tipos de enunciação, os conceitos, as escolhas temáticas, seja possível definir uma regularidade, poder-se á dizer, por convenção, que se trata de uma formação discursiva. Desta forma, a FD, para este autor, apresenta-se como um conjunto de enunciados que se ligam e que se relacionam uns com os outros, colocando em cena determinadas regularidades.

Na Análise de Discurso, essa noção é retomada por Pêcheux associada à teoria das ideologias. Assim, Pêcheux chama de formação discursiva

\begin{abstract}
aquilo que, numa formação ideológica dada, isto é, a partir de uma posição dada numa conjuntura dada, determinada pelo estado da luta de classes, determina o que pode e deve ser dito (articulado sob a forma de uma arenga, de um sermão, de um panfleto, de uma exposição, de um programa etc). (2014, p. 147)
\end{abstract}

Desta forma, os sentidos das palavras podem mudar a depender das posições sustentadas por quem as emprega, ou seja, derivam sentido das formações ideológicas em que tais posições se inscrevem. Assim, é possível dizer que, na $A D$, a noção de formação discursiva não é homogênea, pois comporta em seu interior um espaço de transformação.

A concepção de interdiscurso, de acordo com Courtine \& Marandin, é muito cara para entendermos como funciona a FD, pois

\footnotetext{
o interdiscurso consiste em um processo de reconfiguração incessante no qual uma FD é levada, em função das posições ideológicas que essa FD represente em uma conjuntura determinada, a incorporar elementos pré-construídos produzidos no seu exterior, para nela produzir a redefinição ou o retorno, para igualmente evocar seus próprios elementos, para organizar sua repetição, mas também para provocar nela o apagamento, o esquecimento ou mesmo a denegação. (COURTINE \& MARANDIN, 2016, p. 39-40; grifos dos autores)
}

Isso posto, compreende-se que a FD é heterogênea, bem como o discurso, dado que as fronteiras de uma FD são instáveis e abrem espaço para que elementos vindos do interdiscurso possam causar deslocamentos, rupturas, ou até mesmo o apagamento de saberes que nela são permitidos.

Falar sobre a heterogeneidade discursiva é tratar do efeito do interdiscurso no interior mesmo de uma série de formulações, que constitui o saber "próprio" de uma FD dada, a partir de elementos que vêm do seu exterior. Isto é, a pretensa homogeneidade da FD se dissolve sob a pluralidade nominalista dos "objetos do mundo", marcando, assim, a heterogeneidade que é constitutiva de uma FD (COURTINE \& MARANDIN, 2016, p. 42). 
Desta forma, o sujeito, ao falar, identifica-se com uma FD determinada, reproduzindo os saberes que são permitidos no interior da mesma. Todavia, há um espaço de contradição, visto que a maneira como a posição-sujeito se relaciona com a forma sujeito da FD não é necessariamente homogênea. No seio da FD há distintas posições-sujeito que se relacionam diferentemente com a forma-sujeito que regula esse espaço de dizer, o que reafirma a noção de FD heterogênea.

Segundo Courtine (2016, p. 18-19), uma FD não deve ser pensada como "um único discurso para todos" ou "a cada um o seu discurso", mas sim como "dois (ou vários) discursos em um só", pois a contradição é um princípio constitutivo da FD. Os enunciados, segundo o autor, são "os elementos do saber próprios a uma FD [...] uma forma, ou um esquema geral, que governa a 'repetibilidade' no seio de uma rede de formulações".

O enunciado, conforme Courtine (2016, p. 18-19), forma-se a partir de dois níveis: o interdiscursivo (eixo vertical) e o intradiscursivo (eixo horizontal). É a partir dessa relação que os objetos do discurso se formam, como pré-construídos. Esses foram formulados em condições de produção determinadas e, ao serem incorporados ao discurso, são produzidos em condições de produção outras.

Segundo esse mesmo autor (COURTINE, 2009, p. 74), o interdiscurso é o lugar onde se constituem, para o sujeito falante (que produz uma sequência discursiva dominada por uma FD determinada), os objetos de que esse sujeito do discurso se apropria, tornando-os objetos de seu discurso. Já o intradiscurso de uma sequência discursiva são as articulações entre esses objetos, a partir dos quais o sujeito dá uma coerência à sua declaração. Dessa forma,

\footnotetext{
essa "horizontalização" da dimensão vertical de constituição do enunciado é contemporânea à apropriação por um sujeito enunciador [...], que ocupa um lugar determinado no seio de uma FD, de elementos do saber da FD na enunciação do intradiscurso de uma sequência discursiva, esta em uma situação de enunciação dada. (COURTINE, 2016, p. 24)
}

O que o autor entende, em outras palavras, é que o sujeito, que ocupa uma posição no interior da FD, apropria-se de saberes advindos do interdiscurso, pela via do eixo da formulação (intradiscurso), e produz sequências discursivas em uma situação de enunciação dada.

Conforme Indursky (2013, p. 239-240), é possível dizer que o sentido de uma sequência discursiva não é produzido somente a partir das relações que esta estabelece com outras sequências discursivas no interior de um discurso dado, mas também se dá a partir da relação que estabelece com sua FD de origem e com o interdiscurso. Essa mesma autora compreende que,

\footnotetext{
a produção de sentido faz intervir a memória discursiva que Ihe está associada, permitindo relacionar sequências formuladas no intradiscurso com seu exterior. Somente ao relacionar uma sequência discursiva com a FD que afeta o sujeito do discurso é possível verificar se essa relação é de identidade ou de antagonismo. (INDURSKY, 2013, p. 240)
}

Ao compreendermos que a formação discursiva é o lugar em que o sentido se constitui, somos levados por Pêcheux (2014, p. 149) a entendê-la como tendo a função de "dissimular, na transparência do sentido que nela se forma, a objetividade material contraditória do interdiscurso que determina essa 
formação discursiva como tal", isso quer dizer que há uma objetividade material que determina que algo fala antes, em outro lugar e independentemente.

Isso é dizer que a forma-sujeito, ao absorver-esquecer o interdiscurso no intradiscurso, simula o interdiscurso no intradiscurso, pois o interdiscurso aparece como o puro 'já-dito' do intradiscurso, o que corrobora com a unidade (imaginária) do sujeito, de tal forma que pode chegar a confundi-lo, já que se chega ao ponto de não haver demarcação entre o que é dito e aquilo que advém de outro lugar (PÊCHEUX, 2014, p. 155). Assim, de acordo com Pêcheux, a

\footnotetext{
identificação, fundadora da unidade (imaginária) do sujeito, apóia-se no fato de que os elementos do interdiscurso (sob sua dupla forma ... enquanto "pré-construído" e "processo de sustentação") que constituem, no discurso do sujeito, os traços daquilo que o determina, são re-inscritos no discurso do próprio sujeito. (2014, p. 150; grifos do autor)
}

Portanto, compreender a incorporação dos elementos do interdiscurso é de extrema importância para o nosso trabalho, uma vez que não há fronteiras que demarquem o que é dito no discurso de autodefesa da presidenta e o que advém de outro lugar. Somente chegaremos a compreender como o discurso-outro irrompe no discurso de Dilma a partir de pistas linguísticas e da categoria da memória discursiva.

\section{Relações de confronto através do Discurso relatado marcado (DRM)}

Neste sub-recorte, analisamos a inserção do discurso-outro a partir do discurso relatado marcado. Em tal caso, a heterogeneidade discursiva é explícita, pois o discurso-outro é marcado pelas aspas ou por dois pontos introdutórios (INDURSKY, 2013, p. 243-244).

Para fins de análise, consideramos o que defendem Authier-Revuz e Indursky sobre esta forma de inserção do discurso-outro, para fundamentar a análise que se segue. Nos casos em questão, acreditamos que o sinal gráfico das aspas chama atenção para fragmentos (palavras, expressões) que vêm de outro lugar. De acordo com Authier-Revuz (2016, p. 201), tal sinal produz um efeito de distância e possui dois valores: a "autonímia" e a "conotação autonímica". Indursky, por sua vez, compreende esse sinal gráfico como marca do "discurso relatado marcado" (INDURSKY, 2013, p. 243).

É importante salientar que os termos "autonímia e "conotação autonímica" surgem, segundo Teixeira (2005, p. 141), a partir da configuração teórica de Rey-Debove, a qual ancora seu trabalho no campo da Semiótica. Authier-Revuz parte da compreensão do que sejam tais noções, e mais tarde define "o objeto que seu estudo privilegia: a modalização autonímica" (TEIXEIRA, 2005, p. 141).

Em "Palavras mantidas a distância", Authier-Revuz (2016, p. 201) faz uma distinção entre "autonímia" e "conotação autonímica". Para a autora ${ }^{8}$, o estatuto autônimo do elemento entre aspas é marcado por uma ruptura sintática ou uma ruptura na combinatória que o acompanha, ou seja, não há

8 Optamos por manter num único sub-recorte os casos que Authier-Revuz compreende como conotação-autonímica e autonímia, uma vez que entendemos que tais formas de inserção do discurso-outro dão conta do que Freda Indursky compreende como discurso relatado marcado. 
uso das palavras, mas sim menção a uma palavra $X$ ou $Y$. Assim, esse elemento configura-se como um corpo estranho, um objeto mostrado ao receptor, mantendo-se a distância. Nas palavras da autora:

\begin{abstract}
Na autonímia simples, a heterogeneidade que constitui um fragmento mencionado, entre os elementos linguísticos de que faz uso é acompanhada de uma ruptura sintática. O fragmento citado no interior de um discurso relatado direto ou introduzido por um termo metalinguístico [...] nitidamente delimitado na cadeia discursiva, é apresentado como objeto. (AUTHIER-REVUZ, 1990, p. 29)
\end{abstract}

Já no caso da conotação autonímica, há o que a autora chama de "uso das palavras com conotação de menção", em que os elementos são, sintaticamente, integrados à cadeia discursiva. A conotação autonímica, segundo a autora, atua de duas formas: a partir do discurso indireto livre, no qual não há ruptura sintática que indique que o elemento está integrado ao todo; e a partir de palavras ou sintagmas marcados com aspas de distanciamento (AUTHIER-REVUZ, 2016, p. 202).

A partir do ponto de vista de Indursky (2013, p. 243-244), é possível caracterizar o discurso relatado marcado (DRM) como uma modalidade do discurso relatado, no qual há a citação de palavras, expressões, enunciados entre aspas. Para a autora, o uso das aspas, nas sequências que analisou, indica que foi aberto um espaço no interior do discurso em pauta para palavras, expressões, enunciados, oriundos do discurso do outro. As aspas, segundo essa autora, indicam "[...] o encontro entre discursos e estabelecem fronteiras entre suas FD", a "presença rejeitada do discurso-outro" (INDURSKY, 2013, p. 245246; grifos da autora).

Entendemos que as sequências discursivas (SD) elencadas abaixo se encaixam no que AuthierRevuz chama de "conotação autonímica"; e no que Indursky compreende como "discurso relatado marcado". Vamos dar atenção a cada uma das SD, e compreender o funcionamento discursivo e o efeito de sentido produzido por essa forma de inserção do discurso-outro:

\footnotetext{
SD1: ... desde o início do meu segundo mandato, medidas, ações e reformas necessárias para o país enfrentar a grave crise econômica foram bloqueadas e as chamadas pautas-bomba foram impostas, sob a lógica irresponsável do "quanto pior, melhor". (CARTA)

SD2: ... a força política dos que queriam evitar a continuidade da "sangria" de setores da classe política brasileira, motivada pelas investigações sobre a corrupção e o desvio de dinheiro público. (PRONUNCIAMENTO)
}

Note-se que nas sequências discursivas acima não há uma mudança sintática para a inserção do discurso-outro, pois se faz uso das palavras do outro, acrescentando-o à cadeia sintática, isto é, o elemento aspeado irrompe no discurso do sujeito sem que haja uma organização sintática que mostre que esse discurso é de outrem. $O$ que nos indica que tal elemento vem de outro lugar é a marca das aspas, que demarca uma fronteira entre discursos que se inscrevem em FDs distintas.

As formas marcadas da conotação autonímica são casos mais complexos em que a heterogeneidade se mostra. Segundo Authier-Revuz (2004, p.13), o locutor usa as palavras inscritas no fio de seu discurso, mostrando-as e desdobra-se em observador das palavras do outro. $\mathrm{O}$ fragmento utilizado vem marcado por aspas, por itálico, por uma entonação, e/ou por forma de comentário, recebendo um estatuto outro em relação ao resto do discurso. 
Ao colocar entre aspas os elementos "quanto pior melhor" e "sangria", o sujeito de D1 delimita o que pertence ao seu discurso e o que não pertence, rejeitando o discurso-outro. Isso é dizer que há um embate entre posições-sujeito que pertencem a FDs antagônicas. Há uma separação, uma distância, entre aquilo que é dito pelo sujeito de D1 e o que é dito por sujeitos de D2. Segundo Authier-Revuz,

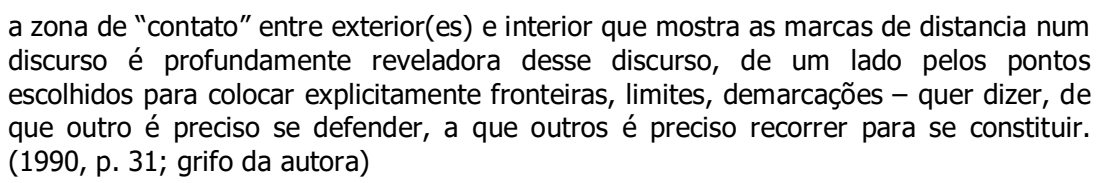

Nesse sentido, nas SD1 e SD2 compreendemos que há uma relação de confronto entre FDs, pois o sujeito de D1 circunscreve o que é permitido em sua FD, incorporando em seu discurso elementos advindos de outra FD, marcado por aspas, demarcando que o que está dentro das aspas não pertence ao seu discurso, mas sim ao outro. Daí haver um embate entre forças antagônicas, ou seja, entre o que é dito a partir da posição-sujeito de D1, com o que é dito em outro lugar a partir de outra posição-sujeito ou, nas palavras de Indursky: "as aspas indicam discordância entre posições de sujeito afetadas por FD antagônicas" (2013, p. 245).

Na SD1 e na SD2, os elementos aspeados compreendem fragmentos de saberes que são interditados na $\mathrm{FDI}^{9}$, isto porque, segundo o sujeito de $\mathrm{D} 1$, a lógica que predomina na $\mathrm{FDE}^{10}$, ou seja, de "quanto pior, melhor" e o termo "sangria" estão em desacordo com a ideologia que subjaz à FDI. Sabemos que tais elementos funcionaram na exterioridade da FD na qual se inscreve o sujeito de D1, de tal modo que há aí a necessidade de marcar com o sinal gráfico que isso vem de outro lugar.

Como mencionado anteriormente, o Discurso relatado marcado "manifesta a presença rejeitada do discurso-outro" (INDURSKY, 2013, p. 246). Ousamos dizer que apesar de o discurso de Dilma, nas condições de produção em que se dá, rejeitar o discurso-outro e buscar a sua desqualificação, marcandoo com as aspas, ainda se vale do mesmo para defender-se. Para Authier-Revuz, as aspas indicam que "uma palavra, durante o discurso, é indicada ao receptor como objeto, o lugar de uma suspensão de responsabilidade" (2016, p. 203; grifos da autora), ou seja, quando o sujeito usa as aspas, indica que o que está aí não é de sua responsabilidade, podendo, inclusive, utilizar um discurso antagônico para sua defesa.

Voltemos ao que conclui Authier-Revuz sobre as marcas explícitas da heterogeneidade discursiva:

Preso na "impenetrável" estranheza de sua própria palavra, o locutor, quando marca explicitamente por formas da distância - pontos de heterogeneidade em seu discurso -, delimita e circunscreve o outro, e, fazendo isso, afirma que o outro não está em toda a parte. (AUTHIER-REVUZ, 2004, p. 72; grifos da autora)

Assim, apesar de o sujeito do discurso circunscrever o outro, marcando-o com as aspas, é possível dizer que esse sujeito está somente denegando algo que já está dado, ou seja, o fato de que toda fala é fundamentalmente heterogênea.

9 FDI: Formação Discursiva Interna, domínio de saber que comporta o discurso governamental e de seus aliados. 10FDE: Formação Discursiva Externa, domínio de saber que comporta o discurso não governamental, representativa de forças políticas e sociais que se opõem ao governo Dilma. 
O recorte que segue é entendido por Authier-Revuz como "autonímia", ou seja, a designação do outro se dá de forma localizada, marcada pelas aspas e com uma ruptura sintática. Indursky, por sua vez, compreende tal funcionamento como DRM:

SD3: O presidente Getúlio Vargas, que nos legou a CLT e a defesa do patrimônio nacional, sofreu uma implacável perseguição; a hedionda trama orquestrada pela chamada "República do Galeão", que o levou ao suicídio. (PRONUNCIAMENTO)

A autonímia ocorre em menor número no discurso em questão, porém, entendemos importante compreender o seu funcionamento discursivo, além de apreender os efeitos de sentido produzidos pela inserção do discurso-outro através desta marca.

Note-se que, nos casos acima, há uma ruptura sintática, diferente dos casos anteriormente analisados. Faz-se menção à "República do Galeão" e ao "devido processo legal", ou seja, esses elementos são introduzidos no fio do discurso sem que se integrem ao todo. O substantivo "chamada", na SD3, rompe a ordem sintática, mostrando o objeto, por assim dizer. Tail elemento possui o que Authier-Revuz chama de "estatuto autônimo" (2016, p. 201), pois o locutor, nesse caso, não faz uso da palavra aspeada, mas sim menção dela.

Na sequência analisada, o sujeito de D1 faz menção à "República do Galeão", marcando-o com as aspas de autonímia. É importante compreender o efeito de sentido produzido pelo uso de tal sinal gráfico, uma vez que o mesmo gera um distanciamento entre o que é produzido pelo sujeito e o que vem de outro lugar, de outro discurso. Neste caso, o sujeito além de fazer menção, mostra, por assim dizer, o elemento que não faz parte do seu discurso, a partir da organização sintática. Daí Authier-Revuz (2008, p. 111) entender que na autonímia há o que ela chama de "mostração de palavras" que são "remetidas ao outro discurso, a mostração de uma mensagem outra".

Lembremos que a "República do Galeão" ficou assim conhecida devido à atuação independente da Base Aérea do Galeão, durante as investigações relativas ao atentado da Toneleros ${ }^{11}$. Importa, para este estudo, compreender as condições de produção de tal acontecimento histórico, dado que este elemento irrompe no discurso da presidenta.

De acordo com Queiroz (2014, p. 60-62), durante o segundo mandato de Getúlio Vargas, havia uma situação política instável, um descontentamento por parte das classes militares. Além disso, havia denúncias de corrupção em órgãos federais, culminando na instalação de uma Comissão Parlamentar de Inquérito para investigar fatos da Administração Federal. Este foi o pano de fundo em que se deu o que ficou conhecido como "Atentado da Rua Toneleros", que ocasionou a morte do Major Aviador Vaz.

Segundo historiadores, a apuração do crime e as circunstâncias do atentado tiveram influência decisiva no fim do Governo Vargas, que findou com o trágico suicídio do presidente (QUEIROZ, 2014, p. 61). Note-se que em oposição à República do Catete, formou-se a "República do Galeão", local onde se faziam as investigações ${ }^{12}$ referentes ao atentado. Tal nome surge devido à autonomia durante as

11 Verbete. Galeão, Republica do. Disponível em: http://www.fgv.br/cpdoc/acervo/dicionarios/verbete-tematico/galeao-republica-do. Acesso em 08/08/2017.

12 Dado que o atentado vitimou um oficial da Aeronáutica, a oposição transformou o inquérito policial, conduzido pela Polícia Civil, num inquérito policial militar (IPM), que ficou sob responsabilidade da Aeronáutica. (Fonte: http://cpdoc.fgv.br/producao/dossies/AEraVargas2/artigos/CrisePolitica/Suicidio. Acesso em 08/08/2017). 
investigações e a amplitude dos poderes que foram conferidos ao grupo que comandava as investigações ${ }^{13}$.

Fazer essa retomada histórica é importante para compreender os efeitos de sentido produzidos pela inserção do discurso-outro no discurso em pauta. Ao aspear o elemento "República do Galeão", o sujeito de D1 estabelece uma relação de confronto com o que aí está marcado. As aspas indicam que tal nomenclatura está em desacordo com o que é permitido a partir da posição que o sujeito ocupa. Surge, em oposição à República do Catete, o que os jornais apelidaram como "República do Galeão". Observe-se que, na carta e no pronunciamento, defende-se a legitimidade do governo. Dessa forma, não é permitido ao sujeito de D1 incorporar ao seu discurso o elemento "República do Galeão" sem que haja um distanciamento, marcado pelas aspas, visto que o mesmo surgiu em discordância a um governo eleito democraticamente. Assim, as aspas indicam que o sujeito de D1 enuncia de uma posição-sujeito que não se identifica com tal saber, ou seja, há uma rejeição por parte do sujeito de D1 dos saberes que circulam na FDE.

A autonímia reflete uma grande tensão entre forças em confronto, de tal modo que é preciso "mostrar" o discurso do outro, para então rechaçá-lo (INDURSKY, 2013, p. 245-246). Acreditamos ser esse o caso em questão, uma vez que, ao marcar com as aspas de autonímia, o sujeito de D1 delimita uma fronteira entre FDs antagônicas e resguarda-se, não havendo o perigo de the ser imputada a ideologia que subjaz à FDE.

É importante salientar que, apesar de a marca das aspas indicar uma fronteira entre o discurso do sujeito de D1 e o discurso de D2, tal marca não garante a fidelidade do que é veiculado. Tal como explicita Authier-Revuz, a marca explícita da heterogeneidade responde à "ameaça que representa, para o desejo de domínio do sujeito falante, o fato de que ele não pode escapar ao domínio de uma fala que, é fundamentalmente heterogênea" (AUTHIER-REVUZ, 2004, p. 73-74). Assim, apesar de marcar com as aspas um distanciamento entre o que pertence ao seu discurso e o que pertence ao discurso do outro, 0 sujeito de D1 está denegando, pois, segundo essa mesma autora "É nesse sentido que a heterogeneidade mostrada pode ser considerada como um modo de denegação no discurso da heterogeneidade constitutiva que depende do outro no um" (AUTHIER-REVUZ, 2004, p. 74; grifos da autora).

Dado o que foi analisado, é possível dizer que, através do DRM, o sujeito de D1 trava um embate de forças que antagonizam entre si, marcando com as aspas que, no intradiscurso, há elementos, fragmentos, que circulam na exterioridade da sua FD. O discurso-outro, assim, é inserido no fio do discurso através do DRM, produzindo o efeito de sentido de rejeição e de busca da desqualificação do discurso-outro. É no fio do discurso que a heterogeneidade discursiva se marca, ou seja, o confronto entre FDs se dá no intradiscurso. Isso é dizer que elementos advindos do interdiscurso são articulados a saberes próprios da FDI, marcados pelas aspas, as quais delimitam fronteiras entre FDs antagônicas.

\section{Relações de confronto através do Discurso relatado indireto formal (DRIF)}

\footnotetext{
13 Faziam parte da investigação, de acordo com Queiroz (2014, p. 67), Nelson Barbosa Sampaio (Promotor Militar); Cordeiro Guerra, que
} acompanhava o inquérito na polícia; 2ำ Tenente Aldo Sartori (escrivão); e Coronel Aviador Adhemar Scaffa de Azevedo Falcão. 
O discurso relatado indireto formal (DRIF), diz respeito ao discurso indireto, entendido por Authier-Revuz como uma tradução do discurso-outro. A autora constata que, nesta modalidade do discurso relatado, "o locutor se comporta como tradutor [...] fazendo uso de suas próprias palavras, ele remete a um outro como fonte do "sentido" dos propósitos que ele relata" (AUTHIER-REVUZ, 2004, p. 12; grifo da autora). Ademais, tal estrutura do discurso relatado possui uma estrutura homogênea, apresentando uma sintaxe normal da língua (AUTHIER-REVUZ, 1998, p. 150).

Para Cunha \& Cintra (2008, p. 652), o discurso indireto é caracterizado pela incorporação de uma informação que vem de outro lugar, isto é, o sujeito que faz uso das palavras do outro se contenta em transmitir ao leitor apenas o conteúdo do que fora relatado, sem nenhum respeito à forma linguística que teria sido realmente empregada. Para o autor, "o emprego do discurso indireto pressupõe um tipo de relato de caráter predominantemente informativo e intelectivo".

Indursky, por sua vez, entende que o discurso relatado indireto formal "corresponde, com exatidão, ao discurso indireto" (INDURSKY, 2013, p. 243), ou seja, acredita que neste funcionamento discursivo não há compromisso com a textualidade, mas sim uma paráfrase do discurso do outro. Para a autora, "[...] o DRIF, ao fundar-se sobre a reformulação das palavras do outro, produz o efeito de homogeneidade." (INDURSKY, 2013, p. 247; grifos da autora), desfazendo-se, assim, a ficção da fidelidade textual, uma vez que o discurso se apresenta sob a modalidade da reformulação, ou seja, não produz, necessariamente, o sentido pretendido pelo sujeito de D2.

Neste tipo de funcionamento discursivo, o sujeito apropria-se de um saber que funciona na exterioridade de sua $\mathrm{FD}$, incorporando-o ao seu discurso, porém, não há compromisso com a textualidade do que foi dito, daí o sujeito poder relatar parcialmente o discurso do outro, bem como dar outra versão do mesmo. Para Indursky (1990, p.119), quando o sujeito mobiliza enunciados produzidos por outros enunciadores, estabelece com eles "relações ideologicamente determinadas de identidade, similaridade, divergência, conflito, antagonismo etc.", isto é, ao relatar o discurso do outro, a relação com o mesmo pode ser dar de maneiras diversas.

Para Cazarin (1998, p. 65), o DRIF constitui-se a partir de um processo de parafrasagem e não mantém compromisso com o que foi dito pelo outro, abrindo espaço ao sujeito do discurso para inseri-lo a seu modo. O DRIF, portanto, não tem como finalidade reproduzir o discurso-outro, mas sim referi-lo. Assim, o sujeito do discurso tem a possibilidade de interpretar, fazendo uma leitura própria do outro discurso, podendo, inclusive, distorcê-lo (CAZARIN, 1998, p.89-90).

Interessa-nos, portanto, compreender o funcionamento discursivo do DRIF no discurso em análise, bem como os efeitos de sentido produzidos por tal forma de inserção do discurso-outro. Para tanto, selecionamos uma sequência discursiva que será analisada, tendo em vista tais objetivos.

SD4: No passado, com as armas, e hoje, com a retórica jurídica, pretendem novamente atentar contra a democracia e contra o Estado do Direito. Se alguns rasgam o seu passado e negociam as benesses do presente, que respondam perante a sua consciência e perante a história pelos atos que praticam. (PRONUNCIAMENTO)

O DRIF, no entender de Indursky, possui uma sintaxe passível de formalização - SN dizer que $X$ - sendo possível substituir o verbo dizer por afirmar, fazer crer, alegar, desejar, pretender, espalhar, propagar, os quais funcionam como verbos introdutores do discurso relatado (INDURSKY, 2013, p. 248). 
De tal modo, é possível dizer, a partir da sequência disposta acima, que tal funcionamento ocorre no discurso em análise, mais precisamente no Pronunciamento feito pela presidenta.

Em alguns casos, o outro é designado por formas verbais que indeterminam seu referente, sendo necessário recorrer à categoria da memória discursiva para apreendê-lo. É o caso da SD4, em que o verbo "pretendem" indica que estamos diante de um sujeito indeterminado. Note-se que o advérbio "novamente" nos dá uma pista, de que tal pretensão - atentar contra a democracia e contra o Estado de Direito - já ocorreu em outras condições de produção. Podemos recuperar tais condições de produção a partir da própria sequência discursiva - No passado, com as armas - sendo possível remeter o discursooutro aos Golpes de Estado sofridos por presidentes anteriores. Note-se que as condições de produção do discurso de Dilma são distintas - e hoje, com a retórica jurídica - porém, o discurso-outro ainda remete para um discurso de direita.

Esta fórmula chama atenção para saberes que circulam na exterioridade da FD na qual se inscreve o sujeito de D1, mas não somente isso, coloca em par de igualdade acontecimentos do passado e do presente, trazendo à tona um forte embate entre forças antagônicas, ou seja, rechaçando o que ocorreu no passado e o que se pretende no presente.

Como dito anteriormente, tal funcionamento discursivo diz respeito ao que Authier-Revuz compreende como discurso indireto. Para essa autora essa forma do discurso relatado é entendida como uma paráfrase discursiva, em que há "uma simples descrição/caracterização do conteúdo do discurso outro sem exigência de equivalência" (AUTHIER-REVUZ, 2008, p. 111), isto é, não há garantias de que o sujeito de D1 relata com fidelidade o discurso do outro.

Portanto, compreendemos que ao trazer para o fio do discurso o que circulou na FD da oposição, o sujeito de D1 o faz na tentativa de defender-se, ou, como afirma Indursky:

Não sendo sempre possível ocultar o discurso do outro este passa a ser representado pelo DRIF, dando margem a interpretações e paráfrases que o mencionam, não sem distorções mais ou menos graves, chegando mesmo a ponto de desfigurá-lo. (2013, p. 248)

A sequência discursiva analisada apresenta o DRIF, como marca de heterogeneidade discursiva mostrada marcada. A análise nos mostra que tal funcionamento discursivo é apreensível a partir da seguinte fórmula: SN dizer que X, como define Indursky (2013, p. 248). Não há linearidade quanto ao verbo introdutor do DRIF, podendo tal modalidade apresentar verbos diversos. Apesar disso, o efeito de sentido produzido por esta modalidade do discurso relatado, no discurso em análise, é o de rejeição, ou seja, o sujeito de D1 se vale do discurso-outro para rejeitá-lo e refutá-lo, evidenciando um confronto no interior do enunciado analisado ${ }^{14}$. Além disso, podemos concluir que essa sequência discursiva produz um efeito de denúncia do discurso do outro, uma vez que coloca em xeque saberes que circulam no interior da FDE.

Ousamos dizer que o discurso de que se ocupa o sujeito de D1 pode romper com a textualidade do que foi dito pelo sujeito de D2. Acreditamos que o processo de parafrasagem (CAZARIN, 1998, p. 65),

\footnotetext{
14 Não queremos, aqui, generalizar um efeito de sentido, bem como a relação que se estabelece a partir do DRIF. É possível que em outro discurso, em outras condições de produção, um sujeito enunciador do discurso se aproprie do discurso-outro, produzindo efeito de sentido diverso. Porém, no caso que analisamos, tal funcionamento discursivo produziu um efeito de sentido de rejeição e uma relação de confronto.
} 
característico do DRIF, não garante que o sentido "pretendido" pelo sujeito de D2 foi mantido pelo sujeito de D1, uma vez que o discurso-outro é inserido no discurso de D1 em outras condições de produção.

A análise ainda nos mostra que o sujeito de D1, ao incorporar no intradiscurso o discurso-outro, 0 faz para confrontar o que diz o outro, isto é, há uma relação de antagonismo entre o que diz o outro e o que diz o sujeito de D1. No caso analisado, portanto, para afirmar o seu discurso e a ideologia que subjaz a sua FD, o sujeito de D1 precisa incorporar ao seu discurso o que diz o outro. Acreditamos que a partir do DRIF o sujeito de D1 rejeita o que diz o outro para defender-se, ao mesmo tempo em que precisa do discurso do outro para afirmar o que pertence ou não a sua FD.

\title{
Relações de confronto através do Discurso relatado indireto informal (DRII)
}

Analisamos, neste sub-recorte, o funcionamento discursivo do discurso relatado indireto informal (DRII), entendido como uma forma não marcada da heterogeneidade mostrada. Discutimos sobre os efeitos de sentido produzidos pela inserção do discurso-outro a partir desta modalidade do discurso relatado. Para tanto, nos valemos do que entende Indursky acerca do mesmo.

Para Indursky, o DRII, assim como o DRIF, "não tem compromisso com a materialidade do textoorigem" (INDURKY, 2013, p. 248), ou seja, o sujeito do discurso pode relatar parcialmente o discurso do outro, podendo traduzir e trair as ideias veiculadas no outro discurso. À diferença do DRIF, o DRII não apresenta uma sintaxe passível de formalização, uma vez que não possui uma sintaxe previsível. Assim, o discurso do outro pode ser relatado por meio de narrativas sucintas, apresentando uma sintaxe bastante variada. (INDURSKY, 2013, p. 248-249).

Ao falar sobre a falta de marcas que indicariam a presença mostrada do outro no discurso, Authier-Revuz (1998, p. 145) destaca que "uma alusão pode [...] não ser reconhecida; mas tal segmento pode também ser identificado, interpretado pelo receptor como vindo de outro lugar, eco de um outro discurso...", ou seja, no discurso do sujeito algo ressoa, chamando atenção para algo que fora produzido anteriormente, em outras condições de produção.

Em "A fala dos quartéis e as outras vozes", Indursky (1998, p. 250-252) elenca uma série de formas sintáticas que funcionam como DRII: construções relativas; sintagmas verbais; sintagmas nominais; frases verbais e frases nominais. Elencamos, abaixo, uma sequência discursiva que será analisada:

\begin{abstract}
SD5: A ameaça mais assustadora desse processo de impeachment sem crime de responsabilidade é congelar por inacreditáveis 20 anos todas as despesas com saúde, educação, saneamento, habitação. É impedir que, por 20 anos, mais crianças e jovens tenham acesso às escolas; que, por 20 anos, as pessoas possam ter melhor atendimento à saúde; que, por 20 anos, as famílias possam sonhar com a casa própria. (PRONUNCIAMENTO)
\end{abstract}

Indursky (2013, p. 248) entende que o DRII pode, apesar da falta de previsibilidade, funcionar como tradutor ou, até mesmo, como traidor do discurso do outro, assim como o DRIF. À diferença do DRIF, o DRII, como dito, não possui uma sintaxe passível de formalização. Assim, é necessário recorrer à categoria da memória discursiva para encontrar um referente para esse discurso. 
O discurso do outro pode ser representado por meio de frases nominais (INDURSKY, 2013, p. 252). É o caso da SD5, a qual não possui forma verbal portadora de marcas de pessoa, número, modo e tempo. Tal funcionamento discursivo do DRII, de acordo com a autora, representa "pré-construídos que podem ser submetidos a uma transformação metodológica", a qual nos permitirá reconhecer um possível discurso do outro, tendo como base a memória discursiva.

Na SD5, a inserção do discurso-outro, apresenta-se a partir de frases verbais, trazendo para o fio do discurso saberes que dizem respeito à ideologia que subjaz à FDE. Porém, tais saberes compreendem ações que serão tomadas, ou seja, ainda não se concretizaram. As frases verbais "congelar por inacreditáveis 20 anos todas as despesas com saúde, educação, saneamento, habitação"; "impedir que, por 20 anos, mais crianças e jovens tenham acesso às escolas"; "que, por 20 anos, as pessoas possam ter melhor atendimento à saúde"; "que, por 20 anos, as famílias possam sonhar com a casa própria.". A partir da memória discursiva, podemos atribuir tal discurso aos saberes da FDE, uma vez que os mesmos funcionaram e funcionam na exterioridade da FDI, mais precisamente, na FD da oposição.

Ademais,

essa rejeição abre espaço para a reorientação do discurso-outro. Isto pode ser observado através do funcionamento discursivo que permite ao sujeito do discurso, a apresentação de um outro ponto de vista, isto é, de um outro discurso próprio de sua FD. (CAZARIN, 1998, p. 92)

No caso analisado, podemos dizer que a partir do DRII o sujeito de D1 incorpora ao seu discurso saberes que funcionaram na exterioridade da sua FD. Esse, o faz a fim de defender-se, marcando no interior do enunciado um confronto. Apesar de o DRII não apresentar marcas explícitas de heterogeneidade discursiva, a partir da categoria da memória discursiva, é possível atribuir determinados elementos que irrompem no intradiscurso como pertencentes à FDE. Desta forma, o sujeito de D1 rejeita o que circula na FDE e determina quais saberes são ideologicamente permitidos no interior de sua FD.

\section{Produzindo um efeito de fechamento}

No presente artigo analisamos, no âmbito da Análise de Discurso de filiação pecheuxtiana, o discurso da presidenta Dilma Vana Rousseff. Tomamos como corpus empírico sua carta de defesa, enviada ao Senado; e seu último pronunciamento, enquanto presidenta, com o objetivo central de analisar a heterogeneidade discursiva presente nos documentos citados. Para tanto, a análise centrou-se na heterogeneidade mostrada (marcada ou não), através do discurso relatado, atentando para: i. o discurso relatado marcado; ii. o discurso relatado indireto formal; iii. o discurso relatado indireto informal; iv. os efeitos de sentido decorrentes da heterogeneidade discursiva.

A partir da análise, foi possível concluir que o sujeito do discurso projeta o outro e a si de maneiras distintas em seu discurso, estabelecendo uma relação de confronto entre FDs. Entendemos, portanto, que tal discurso se apresenta como heterogêneo e se constitui a partir de outros discursos.

Como formas marcadas da heterogeneidade mostrada, identificamos o discurso relatado marcado e o discurso relatado indireto formal. Verificamos, no caso da forma não marcada da heterogeneidade mostrada, o discurso relatado indireto informal. 
Concluímos que os funcionamentos discursivos analisados são marcados por um forte embate entre forças antagônicas, isto é, uma relação de confronto entre FDs antagônicas (FDI x FDE). Porém, para cada funcionamento discursivo, essa relação se lineariza de maneira distinta, ou seja, funciona, discursivamente, de forma diversa.

No DRM, o discurso de D1 é marcado por um sinal gráfico, produzindo um efeito de sentido de rejeição e de desqualificação do discurso do outro. Daí a necessidade de o sujeito de D1 marcar com as aspas o que não pertence à sua FD. No caso do DRIF, a fórmula SN dizer $X$, traz para o fio do discurso o discurso-outro que é rejeitado e denunciado pelo sujeito de D1. Já no caso do DRII, não temos marcas explícitas que indiquem que aí há um outro discurso, sendo necessário recorrer à categoria da memória discursiva. Neste funcionamento discursivo, temos efeitos de sentido de rejeição, de desqualificação e de denúncia do discurso outro.

Concluindo, ao marcar através do discurso relatado o que pertence e o que não pertence ao seu discurso, o sujeito de D1 coloca em xeque o que pertence ao outro, ou seja, são lados e visões de mundo que são postos em cena. O sujeito de D1 tenta, a todo o momento, desconstruir o discurso de D2 colocando em xeque a ideologia que the subjaz, ou seja, buscando desqualificar o discurso que circula na FDE. Além disso, ao circunscrever o que pertence à FDE, o sujeito de D1 afirma seu discurso, o qual antagoniza com o discurso da FDE.

\section{Referências Bibliográficas:}

AUTHIER-REVUZ, Jacqueline. Heterogeneidade(s) enunciativa(s). In: Cad. Est. Ling., Campinas, (19): 25-42, jul./dez. 1990.

Palavras incertas: as não coincidências do dizer. Campinas, SP: Editora da Unicamp, 1998.

Heterogeneidade mostrada e heterogeneidade constitutiva: elementos para uma abordagem do outro no discurso. In: Entre a transparência e a opacidade: um estudo enunciativo do sentido. Porto Alegre: EDIPUCRS, 2004.

A representação do discurso outro: um campo multiplamente heterogêneo. In: Calidoscópio. Vol. 6, no 2, p. 107-119, mai/ago 2008.

. Palavras mantidas a distância. In: Materialidades discursivas. Org: Bernard Conein... [et al.]. Campinas, SP: Editora da Unicamp, 2016.

CAZARIN, Ercília Ana. Heterogeneidade discursiva: relações e efeitos de sentido instaurados pela inserção do discurso-outro no discurso político de L. I. Lula da Silva. Ijuí: Ed. UNIJUÍ, 1998.

COURTINE, Jean-Jacques. Análise do discurso político: o discurso comunista endereçado aos cristãos. São Carlos: EdUFSCar, 2009.

Definição de orientações teóricas e construção de procedimentos em Análise do Discurso. In: Revista de estudos do discurso, imagem e som. Vol. 1, nº 1, 2016.

MARANDIN, Jean-Marie. Que objeto para a Análise de Discurso?. In: Materialidades discursivas. Org. Bernard Conein [et.al.]. Campinas, SP: Editora da Unicamp, 2016.

CUNHA, Celso; CINTRA, Luís F. Lindley. Nova gramática do português contemporâneo. 5 aed. Rio de Janeiro: Lexikon, 2008.

FOUCAULT, Michel. A arqueologia do saber. Tradução de Luiz Felipe Baeta Neves. $7^{a}$ ed. Rio de Janeiro: Forense Universitária, 2008. 
INDURSKY, Freda. Polêmica e Denegação: dois funcionamentos discursivos da negação. In: Cadernos de Estudos Linguísticos. Campinas, Vol. 19, jul./dez. 1990.

. A fala dos quartéis e as outras vozes. Tese de Doutoramento, Campinas, 1992,publicada pela Editora da UNICAMP, 2013.

ORLANDI, Eni, P. Terra à vista! : discurso do confronto: velho e novo mundo. São Paulo: Cortez: Editora da Universidade Estadual de Campinas, 1990.

PÊCHEUX, Michel.Semântica e discurso: uma crítica à afirmação do óbvio. $5^{a}$ ed. Campinas, SP: Editora da Unicamp, 2014.

QUEIROZ, Péricles Aurélio Lima. IPM "República do Galeão": uma abordagem histórica e jurídica. In: Revista do Ministério Público Militar. Ano 39, n 24. Brasília: Procuradoria-Geral de Justiça Militar, 2014.

TEIXEIRA, MARLENE. Análise de discurso e psicanálise: elementos para uma abordagem do sentido no discurso.

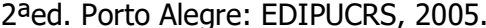

